\title{
Comparative effect of growth media on the monitoring $E$. coli inactivation and regrowth after solar and photo-Fenton
}

\section{treatment}

Pilar Valero ${ }^{a, b}$, Stefanos Giannakis ${ }^{b, *}$, Rosa Mosteo ${ }^{a}$, María P. Ormad ${ }^{a}$, César Pulgarin $^{\mathrm{b}, *}$.

a. Department of Chemical Engineering and Environmental Technologies. University of Zaragoza. 3 María de Luna Street, 50018 Zaragoza, Spain.

b. SB, ISIC, Group of Advanced Oxidation Processes, Ecole Polytechnique Fédérale de Lausanne (EPFL), Station 6, Lausanne, Switzerland.

${ }^{*}$ Corresponding author: César Pulgarin. Adress: SB, ISIC, Group of Advanced Oxidation Processes, Ecole Polytechnique Fédérale de Lausanne (EPFL), Station 6, Lausanne, Switzerland. Tel: +41 216934720. Email: cesar.pulgarin@epfl.ch

${ }^{* *}$ Corresponding author: Stefanos Giannakis. Adress: SB, ISIC, Group of Advanced Oxidation Processes, Ecole Polytechnique Fédérale de Lausanne (EPFL), Station 6, Lausanne, Switzerland. Tel: +41 216930366. Email: stefanos.giannakis@epfl.ch

\begin{abstract}
This study intends to assess the cultivability of photo-treated Escherichia coli K-12 on media with different selectivity (PCA, LBA, T-7, T-7+TTC, VRBA and MAC) and to establish optimal conditions for bacterial recuperation. For these purposes, immediate and long-term bacterial recovery after SODIS and photo-Fenton are evaluated. Moreover, the use of catalase and sodium pyruvate supplements in the medium is studied. The non-selective medium PCA showed the highest counts for the untreated and treated cells due to its content in nutrients (e.g. glucose) and lack of inhibitors. On
\end{abstract}


the contrary, the selective media showed lower recovery, being the culture media effectiveness: $\mathrm{PCA}>\mathrm{LBA}>\mathrm{T}-7>\mathrm{T}-7+\mathrm{TTC}>\mathrm{VRBA}>\mathrm{MAC}$. The presence of inhibitors, such as heptadecyl sulfate in T-7 or bile salts in VRBA and MAC, reduced the cultivability of the treated cells. These compounds can probably diffuse into the cells more easily after SODIS and photo-Fenton as a consequence of the loss of the membrane integrity. In addition, the lack of yeast extract in MAC had a detrimental effect on E. coli recovery. Sodium pyruvate was tested as supplement to PCA, leading to slightly enhanced bacterial immediate recovery after SODIS, SODIS $+\mathrm{H}_{2} \mathrm{O}_{2}$ and photo-Fenton. The addition of catalase and sodium pyruvate to the bulk was studied as well, considerably increasing bacterial survival in the long-term due to their ability to neutralize residual $\mathrm{H}_{2} \mathrm{O}_{2}$.

\section{Graphical Abstract}

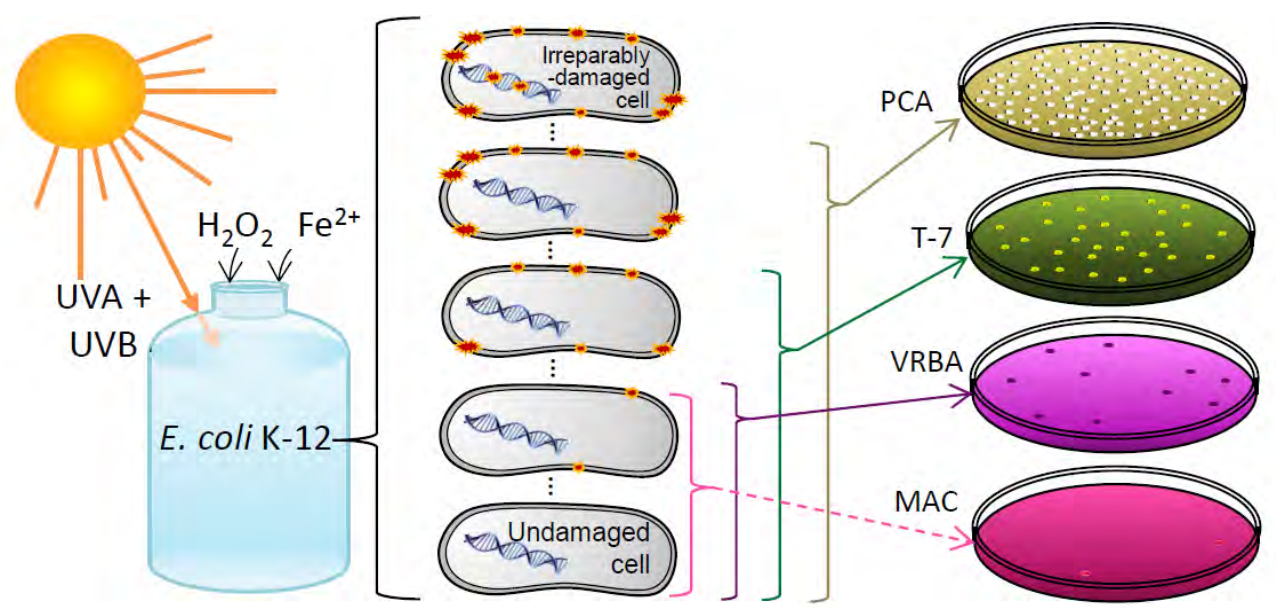

\section{Highlights}

- Selective media noticeably reduced recovery of photo-treated Escherichia coli

- PCA supported the growth of injured bacteria with possible membrane damage

- Catalase and sodium pyruvate enhanced the recuperation of photo-treated $E$. coli

- Photo-Fenton inflicted multi-level cellular damages more severely than SODIS

\section{Keywords}

Escherichia coli; SODIS; photo-Fenton; culture media; catalase; sodium pyruvate 


\section{Introduction}

In an effort to address the issue of a proper and universal access to clean water and sanitation, many researchers have focused on solar-driven techniques as a good alternative for an effective, non-expensive and environmentally-friendly water disinfection treatment [1]. Solar Disinfection (SODIS) consists of placing the water in transparent containers and exposing them to sunlight for several hours. This simple technique achieves high pathogens inactivation by the combined effect UVA+UVB radiation (if the material permits the transmission) and thermal heating [2]. SODIS can be enhanced by the presence of certain substances, such as hydrogen peroxide and/or iron [3], which can be naturally present in the water, thus augmenting the photo-Fenton process $[4,5]$.

Although it often becomes a matter of debate [6], and other techniques have been used to monitor bacteria [7], cultivability is the golden standard when it comes to assessing the efficiency of disinfection processes. Bacterial inactivation efficiency of these and other disinfection treatments is usually assessed by analyzing the cultivability of cells on growth media. Microbial cells are structurally complex so they require culture media that provide a balanced mixture of macronutrients $\left(\mathrm{C}, \mathrm{O}, \mathrm{H}, \mathrm{N}, \mathrm{S}, \mathrm{P}, \mathrm{K}^{+}, \mathrm{Ca}^{2+}, \mathrm{Mg}^{2+}\right.$ and $\mathrm{Fe}^{2+/ 3+}$ ) and micronutrients $(\mathrm{Mn}, \mathrm{Zn}, \mathrm{Co}, \mathrm{Mo}, \mathrm{Ni}$ and $\mathrm{Cu}$ ) [8]. For isolation and enumeration of certain families of microorganisms, many media also contain selective agents, such as toxic compounds and dyes, to inhibit the growth of the non-targeted microorganisms [9].

Escherichia coli is a Gram-negative bacterium used as indicator of fecal pollution in water. For simulation studies in the laboratory, E. coli $\mathrm{K}-12$ is the most popular fecal indicator model, since it is non-pathogenic to humans and it is easily cultivated. When assessing the efficiency of a treatment under controlled laboratory conditions, where there is only E. coli in synthetic samples, non-selective media, such as Plate Count 
Agar or Luria Bertani Agar, are commonly used [10-12]. However, when treating real waters, in which there is a consortium of bacteria, selectivity is required and samples are plated on specific media [13-15]. For example, in drinking water E. coli presence is often analyzed using the selective agars Tergitol-7, MacConkey and Violet Red Bile Agar $[9,16]$. The detection and enumeration of $E$. coli on these media is based on its ability to ferment lactose with acid production denoted by the $\mathrm{pH}$ indicators (bromothymol blue or neutral red) and on the inhibition of Gram-positive bacteria by other compounds (Tergitol-7, bile salts, crystal violet...). Unfortunately, one of the main disadvantages of selective media is that treated bacteria suffering sub-lethal damages are not properly detected [17].

Another drawback related to solar treatments is the risk of bacterial reactivation. Postirradiation events have been reported to be dependent on the applied UV dose [18] and storage conditions such as temperature and availability of nutrients [19]. In addition, regrowth is more likely to happen in the absence of residual $\mathrm{H}_{2} \mathrm{O}_{2}$ [12].

For research purposes, it is common to add some substances to remove the remaining $\mathrm{H}_{2} \mathrm{O}_{2}$ in laboratory assays. For instance, catalase and sodium pyruvate have been used for years as $\mathrm{H}_{2} \mathrm{O}_{2}$ scavengers in samples incubated after SODIS [20-22]. Recently, the addition of catalase to neutralize $\mathrm{H}_{2} \mathrm{O}_{2}$ and study bacterial survival after Fenton processes is becoming more common $[10,12,14,15]$, while the same use for sodium pyruvate has not been found in literature.

The aim of this study is to compare the immediate recovery and possible regrowth in several culture media with different composition and selectivity of Escherichia coli K-12 submitted to different photo-treatments (SODIS, SODIS $+\mathrm{H}_{2} \mathrm{O}_{2}$ and photo-Fenton). Moreover, the addition of catalase and sodium pyruvate will be tested in the agar with the maximum recovery. This approach intends to have a double purpose: i) To assess the effect of the media selectivity on the recovery of photo-treated bacteria and ii) To 
establish optimal conditions in which maximum bacteria recuperation can be obtained, thus reducing the underestimation of bacteria (false negatives) in photo-treatments and the risks associated with it. Ultimately, SODIS and photo-treatment related studies either in lab or field conditions will have a reference of practice and selection of working cultivation media.

\section{Materials and Methods}

\subsection{Chemicals}

Ferrous sulfate heptahydrate $\left(\mathrm{FeSO}_{4} \cdot 7 \mathrm{H}_{2} \mathrm{O}\right)$ (Sigma-Aldrich); Hydrogen peroxide $\left(\mathrm{H}_{2} \mathrm{O}_{2}\right) 30 \%$ w/w (Sigma-Aldrich); Catalase from bovine liver (3000 u/mg SigmaAldrich); Sodium pyruvate $\left(\mathrm{C}_{3} \mathrm{H}_{3} \mathrm{NaO}_{3}\right)$ (Sigma-Aldrich); Hydroxylamine Hydrochloride $\left(\mathrm{NH}_{2} \mathrm{OH} \cdot \mathrm{HCl}\right)$; Ferrozine (Sigma-Aldrich) and Titanium (IV) oxysulfate $\left(\mathrm{TiOSO}_{4}\right)($ Fluka) were purchased from Sigma-Aldrich, Switzerland. All chemicals were reagent grade. Glassware and reactors containing iron were acid soaked after every use to avoid cross-contamination $\left(10 \% \mathrm{HNO}_{3}, 2\right.$ days). All samples and solutions were prepared with Milli-Q water (18.2 M $\Omega-\mathrm{cm})$.

\subsection{Bacterial strain}

Escherichia coli strain K-12 (MG1655) was used for all the experiments. The preparation of the bacteria inoculum was described elsewhere [23]. The resulting $E$. coli suspension has a concentration of $10^{9}$ colony forming units per $\mathrm{mL}(\mathrm{CFU} / \mathrm{mL})$ and the sample was prepared by diluting 1000 times the inoculum in Milli-Q water (i.e. 100 $\mu \mathrm{L}$ E. coli suspension in $100 \mathrm{~mL}$ Milli-Q water), leading to an initial concentration of approximately $10^{6} \mathrm{CFU} / \mathrm{mL}$.

\subsection{Photo-inactivation experiments}


Transparent Pyrex glass reactors containing $100 \mathrm{~mL}$ sample were used for the experiments. The trials were performed in a Suntest solar simulator provided with a Xenon lamp emitting in the UVB, UVA and visible range (similar to solar spectrum) with a radiation intensity of $900 \mathrm{~W} / \mathrm{m}^{2}$. The reactors, properly distributed in the solar simulator, were continuously stirred at $350 \mathrm{rpm}$ during the experiments. Three systems were tested for their photo-inactivation effect on $E$. coli: i) SODIS (hv), ii) SODIS $+\mathrm{H}_{2} \mathrm{O}_{2}$ $\left(h v+\mathrm{H}_{2} \mathrm{O}_{2}\right)$ and iii) photo-Fenton $\left(h v+\mathrm{H}_{2} \mathrm{O}_{2}+\mathrm{Fe}^{2+}\right) . \quad \mathrm{H}_{2} \mathrm{O}_{2}$ and $\mathrm{Fe}^{2+}$ (added as $\mathrm{FeSO}_{4} \cdot 7 \mathrm{H}_{2} \mathrm{O}$ ) concentrations were $10 \mathrm{mg} / \mathrm{L}$ and $0.6 \mathrm{mg} / \mathrm{L}$, respectively. These values were experimentally determined as optimal by Spuhler et al. [12]. $\mathrm{pH}, \mathrm{H}_{2} \mathrm{O}_{2}$ and dissolved iron were concurrently monitored in an additional reactor placed in the solar simulator.

\subsection{Post-irradiation events}

For the post-irradiation monitoring of survival or regrowth of Escherichia coli, aliquots were withdrawn at different treatment times and stored in the dark at $29.5 \pm 0.5^{\circ} \mathrm{C}$. The temperature was selected as representative of the room temperature in the developing countries where SODIS is applied and the treated water is kept in the settlements. Bacterial population was determined every 24 hours after the initial acquisition time for several days, depending on the applied photo-treatment.

In addition, the roles of catalase and sodium pyruvate in post-irradiation events were separately assessed. Catalase or sodium pyruvate were immediately added to the samples prior to storage with concentrations of $900 \mathrm{u} / \mathrm{L}$ and $1 \mathrm{mM}$, respectively.

\subsection{Analytical methods}

Hydrogen peroxide $\left(\mathrm{H}_{2} \mathrm{O}_{2}\right)$ was determined by the titanium oxysulfate method. $1 \mathrm{~mL}$ sample was mixed with $20 \mu \mathrm{L}$ titanium (IV) oxysulfate and measured in a spectrophotometer at $410 \mathrm{~nm}$. Dissolved iron $\left(\mathrm{Fe}^{2+}\right.$ and $\left.\mathrm{Fe}^{3+}\right)$ was analyzed by the ferrozine method, as described elsewhere [12]. Briefly, for $1.6 \mathrm{~mL}$ sample, $0.2 \mathrm{~mL}$ 
hydroxylamine hydrochloride $(10 \% \mathrm{w} / \mathrm{w}), 0.5 \mathrm{~mL}$ acetate buffer $(\mathrm{pH} 4.65)$ and $0.2 \mathrm{~mL}$ ferrozine $(4.9 \mathrm{mM})$ were added. After 20 minutes of reaction, the final coloration was measured at $562 \mathrm{~nm}$ in a spectrophotometer. $\mathrm{pH}$ was monitored with a $\mathrm{pH}$-meter Metrohm 827.

\subsection{Microbiological methods}

\subsubsection{Media}

The recovery of Escherichia coli K-12 was tested on different media: Plate Count Agar (PCA) (Merck); Luria Bertani Agar (LBA); MacConkey Agar (MAC) (Sigma-Aldrich); Violet Red Bile Agar (VRBA) (Sigma-Aldrich); Tergitol-7 Agar (T-7) (Fluka). LBA was prepared with the following composition [9]: $10 \mathrm{~g}$ tryptone (BD Bacto), $5 \mathrm{~g}$ yeast extract (Fluka), $10 \mathrm{~g} \mathrm{NaCl}$ (Sigma-Aldrich) and $15 \mathrm{~g}$ agar (Panreac) were dissolved in $1 \mathrm{~L}$ deionized $\mathrm{H}_{2} \mathrm{O}$. VRBA was made in two different ways: with and without autoclaving it, named as VRBA sterilized and VRBA unsterilized, respectively. As instructed by the manufacturer, unsterilized VRBA improves the recovery of the stressed microorganisms. Tergitol-7 Agar was tested with and without addition of $30 \mathrm{mg} / \mathrm{L}$ triphenyltetrazolium chloride (TTC) (Sigma-Aldrich). Table 1 summarizes the composition of the different media used for the recovery of $E$. coli in this work.

In additional experiments, the effect of including sodium pyruvate, in concentrations of $1 \mathrm{mM}, 10 \mathrm{mM}$ and $100 \mathrm{mM}$, as supplement to PCA medium after autoclaving and before solidification was studied.

\subsubsection{Plating}

Bacterial analysis was carried out according to the spread plate standard method 9215 C. $1 \mathrm{~mL}$ of sample was taken from each reactor and treatment time, and decimal dilutions were made when necessary. For each sample, at least two dilutions were 
plated by duplicate onto each culture media. After 24 hours of incubation at $37^{\circ} \mathrm{C}$, the colonies were counted.

\section{Results}

3.1. Immediate Escherichia coli recovery in different media

\subsubsection{Recovery of untreated E. coli}

Firstly, a preliminary experiment to assess Escherichia coli K-12 growth on the different tested media was conducted. Each untreated sample was plated onto seven culture media. Fig. 1 represents the percentage of recovery on each agar compared to PCA, considering the log values of the counting. PCA presented the highest numbers $\left(3.5 \cdot 10^{6} \pm 7.2 \cdot 10^{5} \mathrm{CFU} / \mathrm{mL}\right)$, closely followed by LBA $\left(3.3 \cdot 10^{6} \pm 6.9 \cdot 10^{5} \mathrm{CFU} / \mathrm{mL}\right)$, Tergitol-7 with TTC supplement $\left(3.3 \cdot 10^{6} \pm 3.9 \cdot 10^{5} \quad \mathrm{CFU} / \mathrm{mL}\right)$ and without it $\left(3.2 \cdot 10^{6} \pm 6.1 \cdot 10^{5} \mathrm{CFU} / \mathrm{mL}\right)$ and VRBA unsterilized $\left(3.1 \cdot 10^{6} \pm 7.3 \cdot 10^{5} \mathrm{CFU} / \mathrm{mL}\right)$ or sterilized $\left(3.0 \cdot 10^{6} \pm 6.9 \cdot 10^{5} \mathrm{CFU} / \mathrm{mL}\right)$. The lowest $E$. coli enumeration $\left(1.1 \cdot 10^{6} \pm 1.0 \cdot 10^{6}\right.$ $\mathrm{CFU} / \mathrm{mL}$ ) was observed in MacConkey agar. The initial tests confirmed that, except for MAC agar, the media can support sufficiently well the growth of healthy, non-treated microorganisms.

\subsubsection{Recovery of photo-treated E. coli}

Fig. 2 shows the immediate recovery of Escherichia coli spread onto different media after solar disinfection (Fig.2a) and photo-Fenton (Fig.2b). Important differences on $E$. coli inactivation were observed depending on the type of agar. Culture media effectiveness for treated bacteria recovery followed this order in both cases: PCA > LBA $>$ Tergitol-7 $>$ T-7+TTC $>$ VRBA sterilized $=$ VRBA unsterilized $>$ MAC.

The final $\mathrm{pH}$ was around $\mathrm{pH} 6$ for SODIS tests and did not drop under 5 in the photoFenton assays. Therefore, cell damage and consequent loss of cultivability were light- 
induced. As expected, photo-Fenton produced much faster inactivation than SODIS. Taking into account the most favorable medium for E. coli recovery (i.e. PCA), total inactivation (6-log reduction) was achieved in 60 min during photo-Fenton, while only 4 log units were removed in 180 min when applying artificial solar light alone. As it can be seen in Fig.2, LBA and Tergitol-7 Agar followed similar trends when the sample was exposed to light only, but differed during photo-Fenton, with LBA efficiency being very close to PCA for the first 30 minutes of treatment in the latter case. It can be also observed that at some points recovery on Tergitol-7+TTC led to counts slightly inferior than in Tergitol-7 alone. Regarding the performance of VRBA, poor E. coli growth took place and omitting sterilization of the medium did not enhance the recovery of stressed bacteria. MacConkey agar presented a singular behavior. Even initial recovery of untreated cells was lower (which is in agreement with results in Fig.1) and, whereas disinfection curves showed a kind of shoulder in all the other culture media, bacterial inactivation in MAC dropped by linear decay from the beginning.

A growth restriction ratio, defined as the time to reach detection limit in PCA divided by the time needed to reach detection limit in the other media [Eq. (1)], will be used for further comparison. The higher the ratio is, the higher the inability of $E$. coli to grow in the medium is.

Growth restriction ratio $=\frac{t_{D L}^{P C A}}{t_{D L}^{\text {medium }}}$

As detection limit was not reached in SODIS when plating in some media (PCA, LBA, T-7+TTC and T-7), time for total inactivation has been calculated from disinfection kinetics $\left(\mathrm{k}_{\mathrm{PCA}}=0.030 \mathrm{~min}^{-1}, \mathrm{k}_{\mathrm{LBA}}=0.040 \mathrm{~min}^{-1}, \mathrm{k}_{\mathrm{T}-7+\mathrm{TTC}}=0.043 \mathrm{~min}^{-1}, \mathrm{k}_{\mathrm{T}-7}=0.047 \mathrm{~min}^{-1}\right)$. The predicted values would be $269 \mathrm{~min}, 214 \mathrm{~min}, 188 \mathrm{~min}$ and $189 \mathrm{~min}$, respectively. Consequently, the growth restriction ratios in SODIS were 1.3 for LBA, 1.4 for T-7 and T-7+TTC and 2.0 for VRBA (sterilized and unsterilized) and MAC. The growth restriction ratios in photo-Fenton (Fig.2b.) were 1.5 for LBA, T-7 and T-7+TTC and 2.0 
for VRBA and MAC; this means that E. coli actually remained in the sample for 2 or 1.5 times longer than estimated by VRBA and MAC or by T-7 and LBA, respectively. The ratios, and consequently the inhibition, for T-7, T-7+TTC and LBA are comparable and so are for VRBA and MAC. In addition, the values of the ratios are quite alike for each agar in both systems, meaning that the selective media posed similar restrictions to growth regardless the applied treatment.

Finally, it has to be mentioned that as treatment time increased, more significant differences in bacterial recuperation among the studied media were observed. Most probably, this effect is attributed to the greater number of injured cells which were unable to develop in the presence of the selective compounds. These results suggest that there is a synergistic-like phenomenon between cell damage and media composition, which involves an additional inhibitory effect, especially noticeable in VRBA and MAC agars. The presence of bile salts in these media, along with the lack of yeast extract in MAC, might reduce their capacity to support the growth of phototreated E. coli.

\subsection{Post-irradiation survival or regrowth of Escherichia coli}

Considering the similarities that some of the studied media presented, as showed in section 3.1., post-irradiation survival or regrowth of E. coli was only tested on PCA, Tergitol-7 agar, VRBA and MacConkey agar.

\subsubsection{Post-irradiation events after SODIS treatment}

Fig.3 (a-d) represents bacterial post-irradiation events after exposure of the sample to simulated solar light for different time periods $(0,30,60,90,120$ and $180 \mathrm{~min})$. The withdrawn aliquots were stored in the dark at $29.5^{\circ} \mathrm{C}$ and analyzed in four different media every 24 hours up to 96 h. Firstly, it has to be noticed that no regrowth occurred for any irradiation time. The treated cells might have been unable to experiment propagation because: i) the relatively high, and not intermittent, irradiation doses 
applied (considering that the light intensity was $900 \mathrm{~W} / \mathrm{m}^{2}$ ) caused irreparable damages, ii) there was a lack of nutrients in the water matrix (i.e. Milli-Q water) and iii) cells suffered from osmotic stress.

Secondly, as shown in Fig. 3 and in Table 2, bacteria photo-treated for longer periods presented faster a loss of long-term bacterial viability. In the aliquot irradiated for 30 min E. coli survival was very similar to that of the untreated cells within $48 \mathrm{~h}$ when plated on the most favorable medium (i.e. PCA), so, in this case, immediate severe photo-damage was not induced. Subsequent inactivation $(>48 \mathrm{~h})$ might be related to minor injuries combined with starvation and osmotic stress. However, 60 min or longer exposures to SODIS caused direct mortality and prevented regrowth. Therefore, in all the media there is a correlation between the accumulated cellular photo-damage and the inability of E. coli to survive.

Concerning bacterial long-term recovery on the different media, the presence of selective compounds had a detrimental effect. Aliquots spread onto PCA showed more than $96 \mathrm{~h}$ survival in the dark after $120 \mathrm{~min}$ or shorter exposure to SODIS and total decay only happened within 48 hours when the treatment lasted 180 minutes (Fig. 3a). However, when the same aliquots were plated on the other media, all of them containing substances which confer various degrees of selectivity, lower recovery was achieved. On Tergitol-7 (Fig. 3b), detection limit was reached after $48 \mathrm{~h}$ and $24 \mathrm{~h}$ if exposed to 90 min or 120 min SODIS, respectively and E. coli survived longer than 96 h only when photo-treated for 30 min or 60 min. On VRBA and MAC agars (Figs. 3c and $3 \mathrm{~d}$ ), bacterial survival beyond $96 \mathrm{~h}$ only took place when plating the $30 \mathrm{~min}$-treated aliquot.

The fact that after a certain time of irradiation and subsequent storage in the dark, $E$. coli was able to grow on PCA, but limited or no recovery occurred in the other media suggests that there are sub-lethally injured cells whose cultivability strongly depends 
on media composition. Selective compounds impair the recuperation of cells which are damaged but still are cultivable in PCA.

\subsubsection{Post-irradiation events after photo-Fenton treatment}

Fig. 4 (a-d) illustrates the post-irradiation events in the dark in the presence of catalase after applying the photo-Fenton process for $0,15,30,45$ and $60 \mathrm{~min}$. The stored samples were analyzed every $24 \mathrm{~h}$.

First thing to stand out is that no regrowth was observed during this experiment. Secondly, photo-Fenton clearly demonstrated a superior disinfection power than the artificial solar light alone. For instance, $30 \mathrm{~min}$ of photo-Fenton led to total inactivation (6 log reduction) after $24 \mathrm{~h}$ (in T-7, VRBA and MAC; Figs. 4b-d) or after $72 \mathrm{~h}$ (in PCA; Fig. 4a), whereas 30 min of SODIS reduced bacterial population less than 3 log within $96 \mathrm{~h}$ in any of the culture media (Fig. 3). Even very short exposure to photo-Fenton (i.e. $15 \mathrm{~min}$ ) involved immediate irreparable cellular damage and long-term inability to survive (Fig. 4). Besides, for a certain number of surviving bacteria, total decay was sooner achieved in photo-Fenton than in SODIS (e.g. $\sim 4 \cdot 10^{5} \mathrm{CFU} / \mathrm{mL}$, Figs. $3 \mathrm{~b}$ and 4b). Despite the fact that $\mathrm{H}_{2} \mathrm{O}_{2}$ in the bulk was neutralized with catalase, the "residual" effect of photo-Fenton was more noticeable than that of solar disinfection; hence, bacterial injury was more pronounced in the former treatment, since solar light alone inactivation mode of action relies in a considerable percentage in damages that can be repaired, i.e. DNA mutations. Our results suggest that photo-Fenton mode of action inflicts multi-level damage internally and externally, and bacterial recovery potential is diminished. Combined with the selective agents in the different media, the cultivability is severely restricted.

Moreover, E. coli survival in the dark after the photo-Fenton process was also studied without catalase addition (see Supplementary material Fig. S1). No recovery was observed after 24 hours in all the cases except for $E$. coli treated for $15 \mathrm{~min}$ and plated 
in PCA, which survived $48 \mathrm{~h}$. In the absence of catalase, unreacted $\mathrm{H}_{2} \mathrm{O}_{2}$ might have continued bacterial inactivation in the dark, especially if the cells were already injured and their permeability had increased [24], thus contributing to cause internal cellular damage.

Again, among the different media tested, only PCA detected viable cells for longer (Fig. 4). Recovery on T-7, VRBA and MAC agars showed some similarities, with total inactivation achieved within $24 \mathrm{~h}$ for the 30 min-treated sample and within $72 \mathrm{~h}$ for the 15 min-treated one. Nevertheless, analysis of those aliquots on PCA presented higher survival of $E$. coli $(72 \mathrm{~h}$ and $>72 \mathrm{~h}$, respectively). Consequently, keeping in mind the purpose of this research, PCA was considered the best media for further studies involving supplement addition when laboratory, controlled conditions are involved. For natural bacterial consortia from field tests, T-7 without TTC would be recommended for minimum cultivability reduction.

\subsection{Enhanced immediate $E$. coli recovery and regrowth with sodium pyruvate}

This part of the research deals with the effect of using the supplement sodium pyruvate (SP) to provide optimal conditions for the recovery of photo-treated bacteria. Sodium pyruvate was added either during agar preparation or directly into the treated sample.

\subsubsection{Sodium pyruvate added to the culture plates}

Fig. 5 a-c shows the efficiency of PCA medium containing different concentrations of sodium pyruvate $(0 \mathrm{mM}, 1 \mathrm{mM}, 10 \mathrm{mM}$ and $100 \mathrm{mM} \mathrm{SP})$ on the immediate recovery of E. coli after SODIS, SODIS $+\mathrm{H}_{2} \mathrm{O}_{2}$ and photo-Fenton. Results are expressed as percentage (considering the values in logarithmic scale) compared to recovery on PCA without sodium pyruvate. In general, the use of sodium pyruvate in the PCA plates enhanced bacterial recovery, especially as treatment time passed and damage was accumulating in the cells. Note that for 90 min of $\mathrm{SODIS}+\mathrm{H}_{2} \mathrm{O}_{2}$, bacterial count in $\mathrm{PCA}+100 \mathrm{mM}$ SP is the same than in PCA without SP because detection limit was 
reached on that experiment. Fig. 5 also shows that increasing amounts of sodium pyruvate progressively improved $E$. coli recuperation. If the different treatments are compared, SP permitted a maximum increase in growth of $6 \%, 14 \%$ and $30 \%$ for SODIS, SODIS $+\mathrm{H}_{2} \mathrm{O}_{2}$ and photo-Fenton, respectively. The presence of unreacted hydrogen peroxide remaining in the samples after SODIS $+\mathrm{H}_{2} \mathrm{O}_{2}$ and photo-Fenton (see Supplementary material Fig. S2) might have contributed to cause bacterial injuries even once plated, but the sodium pyruvate included in the agar could probably react with this excess of $\mathrm{H}_{2} \mathrm{O}_{2}$ and prevent further cell damages. During SODIS, no exogenous $\mathrm{H}_{2} \mathrm{O}_{2}$ was added; however its production and accumulation inside the cell must have been neutralized by SP.

\subsubsection{Sodium pyruvate added to the bacterial suspension}

Sodium pyruvate was added to the photo-treated aliquots with a final concentration of 1 $\mathrm{mM}$. The samples were stored in the dark and the post-irradiation events were studied, using PCA as the culture medium.

Fig. 6 illustrates the bacterial survival in the dark after the different photo-treatments when the aliquots were stored in the absence or presence of $1 \mathrm{mM} \mathrm{SP}$.

When applying SODIS (Fig. 6 a and b), immediate recovery was not affected by sodium pyruvate (see Supplementary material Fig. S3a), possibly because of its presence in the employed low concentration (1 mM SP), which had also low impact when inserted in the medium (Fig. 5). Addition of SP to the bulk enhanced bacterial survival in the long-term, although no regrowth occurred. The most remarkable fact in Figs. $6 a$ and $6 \mathrm{~b}$ is that when bacteria were exposed for $120 \mathrm{~min}$ of light, posterior survival was noticeably enhanced in the presence of SP $(>72 \mathrm{~h})$, while total inactivation occurred within 24 hours when no supplement was added. In addition, for longer treatment times, higher enhancing effect of sodium pyruvate on recovery was observed. This is further proof of the intracellular $\mathrm{H}_{2} \mathrm{O}_{2}$ accumulation during SODIS, 
able to affect the post-irradiation survival events. After 48 hours of storage, inactivation started to be noticeable even in the untreated sample ( $0 \mathrm{~min}$, blue line $)$, so, from that time on, starvation and osmotic stress might have been important facts for the loss of cultivability.

Survival in the dark with SP addition to the sample after photo-Fenton is showed in Figs. $6 e$ and f. Photo-Fenton was the most aggressive treatment and only bacteria shortly exposed ( $\leq 30 \mathrm{~min})$ could survive for more than 1 day. SP clearly increased bacterial survival in $1 \log$ and $3 \log$ for $15 \mathrm{~min}$ and 30 min-treated cells, respectively, after $24 \mathrm{~h}$.

\section{Discussion}

4.1. Mode of action of SODIS (hv), SODIS $+\mathrm{H}_{2} \mathrm{O}_{2}\left(h v+\mathrm{H}_{2} \mathrm{O}_{2}\right)$ and photo-Fenton $\left(h v+\mathrm{H}_{2} \mathrm{O}_{2}+\mathrm{Fe}^{2+}\right)$.

Bacteria undergoing SODIS are mainly inactivated by the exposure to wavelengths UVA (320-400 nm) and UVB (280-320 nm) present in solar light [1]. Despite the fact that only small quantities of UVB reach the earth surface, its contribution to solar disinfection can be significant, if the reactor material does not filter it out [25]. Radiation in the UVB can be absorbed by cellular DNA components causing important lesions in pyrimidine and purine bases [26-28] which finally lead to cellular mutations or even cell death [25]. Direct DNA damage can also occur in the presence of UVA light, but to a lower extent that with UVB [4]. In fact, the predominant UVA damage is attributed to the absorption of UVA photons by endogenous photosensitizers inducing photo-oxidation reactions type I and II which involve the formation of reactive oxygen species (ROS) $[28,29]$. Moreover, an internal Fenton process can happen during UVA exposure if $\mathrm{H}_{2} \mathrm{O}_{2}$ produced via cellular respiration (along with $\mathrm{O}_{2}{ }^{-}$) [30] or by activation of flavoenzymes [31] reacts with free iron released from ferritins [32] or from oxidation of 
iron-sulfur clusters [30] or enterobactin proteins [33]. As a result, the ROS generated in photo-oxidation and Fenton reactions, including the highly reactive ${ }^{*} \mathrm{OH}$, attack DNA, RNA, lipids and proteins, thus initiating complex chain reactions that end up in loss of cell functions, mutations and DNA replication block [34]. More precisely, Berney et al. [24] observed that as UVA light dose increase, E. coli experiments reduction of efflux pump activity and ATP synthesis, loss of membrane potential, glucose uptake activity and cultivability and, finally, permeabilization of the cytoplasmic membrane.

In the presence of $10 \mathrm{mg} / \mathrm{L} \mathrm{H}_{2} \mathrm{O}_{2}$ the bacterial photo-inactivation was considerably enhanced (Figs. $6 c$ and $6 \mathrm{~d}$ ). There are several possible pathways that explain this improvement in Milli-Q water [4, 12, 30]: i) direct membrane attack by $\mathrm{H}_{2} \mathrm{O}_{2}$ and its derived oxygen species, ii) diffusion of external $\mathrm{H}_{2} \mathrm{O}_{2}$ into the cell, iii) increase of free iron release by $\mathrm{H}_{2} \mathrm{O}_{2}$-assisted oxidation of the sulfur clusters and iv) damage by UVA light of the ROS- regulating enzymes (i.e. catalase, peroxidase and superoxide dismutase). The combination of these mechanisms leads to an enhanced intracellular Fenton that causes ROS accumulation and consequent oxidative stress. The observed hydrogen peroxide consumption when combined with artificial solar light (see Supplementary material Fig. S2a) implies its increased intracellular reaction and the formation of ROS, subsequently inactivating E. coli cells.

When the photo-Fenton system $\left(h v / \mathrm{H}_{2} \mathrm{O}_{2} / \mathrm{Fe}^{2+}\right)$ was implemented, disinfection was faster with shorter delay on initial bacterial inactivation (Fig. 2b). Iron was added as $\mathrm{FeSO}_{4}$ to have available ferrous ions $\left(\mathrm{Fe}^{2+}\right)$, but the fast drop in total dissolved iron concentration (see Supplementary material Fig. S2b) suggest that, in the presence of $\mathrm{H}_{2} \mathrm{O}_{2}$ and at near neutral $\mathrm{pH}(\sim 5), \mathrm{Fe}^{2+}$ was rapidly oxidized to $\mathrm{Fe}^{3+}$, thus forming iron species such as oxides and hydroxides (e.g. $\mathrm{Fe}(\mathrm{OH})^{2+}$ ), which are insoluble [35]. However, $\mathrm{Fe}^{3+}$ irradiated with UV light undergoes photochemical reduction to $\mathrm{Fe}^{2+}$ completing the redox cycle of iron [36]. Consequently, reactive oxygen species are expected to be generated according to the following reactions (Eqs. (2)-(4)): 
$\mathrm{Fe}^{2+}+\mathrm{H}_{2} \mathrm{O}_{2} \rightarrow \mathrm{Fe}^{3+}+{ }^{*} \mathrm{OH}+\mathrm{OH}^{-}$

$\mathrm{Fe}^{3+}+\mathrm{H}_{2} \mathrm{O}_{2} \rightarrow \mathrm{Fe}^{2+}+\mathrm{HO}_{2}^{*}+\mathrm{H}^{+}$

$\mathrm{Fe}(\mathrm{OH})^{2+}+h v \rightarrow \mathrm{Fe}^{2+}+{ }^{*} \mathrm{OH}$

The existence of $\mathrm{H}_{2} \mathrm{O}_{2}$ and iron species in the water implies more efficient bacterial removal for several reasons. External hydrogen peroxide may increase permeability of the membrane, so $\mathrm{Fe}^{2+}$ can more easily diffuse into the cell contributing to the internal formation of ROS by the (photo)-Fenton process [12]. Additionally, exogenous ROS generated by external photo-Fenton reactions might attack the membrane, eventually causing cellular dysfunction by oxidative stress [35].

\subsection{Cell repair possibilities}

Experimental results showed no regrowth in the dark after the photo-treatments (Figs. $3,4,6-8)$ and, in general, E. coli post-irradiation survival was observed only for low UV doses (i.e. shorter treatment times) while for higher doses (i.e. longer exposure) detection limit was reached during the photo-treatment. Therefore, cells probably experienced immediate sub-lethal and lethal photo-damages, along with starvation and osmotic stress on the long term.

In principle, organisms are provided with repair mechanisms to counteract the lethal effects of DNA lesions. For instance, photo reactivation, controlled by the photolyase enzyme, is one of the simplest reparation mechanisms [25]. Nevertheless, the storage of the pre-treated samples was carried in the dark; hence, other restoration pathways like base excision repair, Pol $\vee$ polymerase, lesion bypass or recombinational repair took place. Small colony variants, considered as mutations resulting from DNA damage by UV radiation and/or subsequent repair [37], were observed especially after SODIS (see Supplementary material Fig. S4). 
On the other hand, oxidative stress can in turn induce the response of superoxide dismutases (FeSOD and MnSOD), glutathione reductase, peroxidases and catalases, which are enzymes that scavenge the intracellular ROS, thus preventing their accumulation [38]. Oxidized iron-sulfur clusters can also be repaired to the reduced form, but the mechanisms remain unclear [39]. Moreover, proteins, which are a target of ROS as well, especially through Fenton chemistry when iron is bound to polypeptides, might have their structure recovered by reduction of oxidized disulfide bonds [34].

Establishing to which extent each of the different destruction and repair mechanisms took place is complex and would require numerous analyses. However, it could be said that the repair mechanisms were not enough to cope with all the inflicted damage, since no reactivation was observed. It was also evident that photo-Fenton caused more severe, irreparable injuries than SODIS and reduced bacterial survival opportunities. Besides, the possible presence of $\mathrm{H}_{2} \mathrm{O}_{2}$ and the absence of nutrients and of osmotic balance caused by the Milli-Q water have to be considered. Storage of photo-damaged bacteria under unfavorable conditions reduces dehydrogenase activity, membrane potential and membrane integrity [40] and eventually contributes to the decay of the $E$. coli concentration [19].

\subsection{Culture media composition affecting cultivability of untreated cells}

Culture media are continuously evolving to faster provide more accurate results. Some of the most desired characteristics of the media are sensitivity and specificity [41]. Unfortunately, selective media are not always able to detect all the targeted microorganisms because of the growth inhibition caused by the selective agents [17]. Consequently, general or non-selective agars containing only nutrients, such as PCA and LBA, are expected to have higher recovery rates. 
Counts of untreated E. coli were only slightly superior on PCA than in the other agars (Fig. 1). Regarding the selective media tested, Tergitol-7 agar, which contains sodium heptadecyl sulfate (Tergitol-7) and bromothymol blue acting as inhibitors of grampositive bacteria, allowed high Escherichia coli recuperation [42, 43]. VRBA and MacConkey agar include bile salts, crystal violet and neutral red as inhibitors of grampositive microorganisms and/or dyes for differentiation. Despite the high tolerance of $E$. coli to bile salts, the outer membrane barrier can only retard the influx of this component [44], which, in addition, might increase cellular permeability [45]. Moreover, Berstein et al. [46] reported that bile salts induced expression of specific stress response genes related to membrane perturbation, oxidative stress and DNA damage. Crystal violet presents bacteriostatic and bactericidal actions against several bacteria [47]. In E. coli these effects are less significant because of the high isoelectric point and lower acidic content which leads to an slower combination of the dye and this gramnegative microorganism [48]. Neutral red has also demonstrated to cause loss of viability of E. coli and it might induce SOD response [49]. Yet, under normal conditions, untreated $E$. coli is apparently able to cope with these substances in VRBA (Fig. 1).

On the contrary, low counts were obtained in MacConkey agar when plating undamaged cells. While PCA, LBA, T-7 and VRBA can provide all short of nutrients to the cells, MAC agar lacks yeast extract, which is an excellent source of vitamins from group B. Vitamins conduct essential functions in the cell; therefore, they are necessary, even in very small quantities, to promote microbial growth [8]. Since some strains of $E$. coli are unable to synthetize certain vitamins, such as vitamin B12 [50], they need to obtain them from the environment. Deficiency of vitamins B in this medium could mean failure of some cellular functions such as the transport of methyl groups, electrons or hydrogen atoms [8], thus limiting E. coli growth.

4.4. Cultivability of photo-treated cells in different media 
The experimental results showed a synergy between photo-damage in bacteria and their ability to grow on different media. The highest recovery of light-exposed cells was achieved in the general medium PCA, in which, unlike the other tested media, glucose was available (Table 1). During solar disinfection cellular glucose uptake activity drops, meaning that the PEP-PTS system, which is in charge of the transport of external sugars into the cell, is compromised [24]. When spread onto PCA the cells might still be able to use some glucose as source of energy for their growth, even if the PEP-PTS system is not fully operating. This extra nutrient and the absence of inhibitors may also benefit the recovery of the starved photo-treated bacteria.

T-7 agar intermediate effectiveness in the short and in the long term recovery might be related to the adverse effects of sodium heptadecyl sulfate and bromothymol blue. Reduction on the recovery of injured coliform bacteria in the presence of Tergitol-7 has been previously observed [51] and it may be the result of increased sensitivity to detergents [52], such as Tergitol-7, caused by lipid peroxidation in membranes of ROSattacked cells [34]. Besides, the bromothymol blue dye is able to inhibit the growth of some strains of E. coli under specific conditions [53]. The additive TTC also led to smaller counts on Tergitol-7, since TTC reacts with dehydrogenases and this affects the respiratory chain of the cell [54].

The diminished growth on VRBA and MAC agar was noticeably impaired by the selective components. The influx of bile salts through a compromised membrane eventually produces growth inhibition [44] and crystal violet can reach the cytoplasm of E. coli cells whose outer membrane has been altered, being their survival inversely correlated to the accumulation of the dye $[55,56]$. Moreover, growth inhibition of treated or stressed $E$. coli in the presence of neutral red and $\mathrm{NaCl}$ has also been reported [17]. 
Considering these facts, although the internal processes are of outmost importance for the viability of the cell, it is possible that membrane integrity is a determining factor on the cultivability of photo-treated bacteria. As treatment time increases, membrane damage is greater and cellular accumulation of toxic inhibitory substances from the media is more likely to happen. It might be possible that $E$. coli presenting unimportant or no damage in the cell wall are able to grow in VRBA and MAC, while in Tergitol-7 and especially in PCA more harmed cells can be recovered.

\subsection{Enhanced recovery with supplements}

After light exposure, the unreacted $\mathrm{H}_{2} \mathrm{O}_{2}$ has a residual effect because it is able to promote dark Fenton reactions, thus impairing cell survival [12]. Consequently, if $\mathrm{H}_{2} \mathrm{O}_{2}$ is removed from the system, further oxidative cellular damage by ROS should not be expected, although inactivation can continue to happen due to irreparable cellular damages and starvation, along with the adverse effects caused when plating on selective media. Some substances can be added to scavenge hydrogen peroxide, such as catalase or sodium pyruvate. Catalase, which is an enzyme produced endogenously by the cells, is able to catalyze $\mathrm{H}_{2} \mathrm{O}_{2}$ decomposition (Eq. (5)) [39], while sodium pyruvate reacts with $\mathrm{H}_{2} \mathrm{O}_{2}$ producing decarboxylation of the molecule (Eq. (6)) [57]:

$\mathrm{H}_{2} \mathrm{O}_{2}+\mathrm{H}_{2} \mathrm{O}_{2} \rightarrow \mathrm{O}_{2}+2 \mathrm{H}_{2} \mathrm{O}$

$\mathrm{CH}_{3} \mathrm{COCOONa}+\mathrm{H}_{2} \mathrm{O}_{2} \rightarrow \mathrm{CH}_{3} \mathrm{COOH}+\mathrm{CO}_{2}+\mathrm{Na}^{+}+\mathrm{OH}^{-}$

Catalase is commonly applied over the prepared medium to stop the residual effect of $\mathrm{H}_{2} \mathrm{O}_{2}$ after SODIS, SODIS $+\mathrm{H}_{2} \mathrm{O}_{2}$ and photo-Fenton [12, 21], while sodium pyruvate is usually incorporated to the medium before autoclaving and incubation is carried out under anaerobiosis to provide optimal recovery conditions [22, 24, 58]. Moreover, no use of sodium pyruvate to enhance photo-Fenton-treated bacteria recuperation has been found in literature. 
In this study, sodium pyruvate slightly enhanced the immediate recovery of phototreated cells (especially when added in the medium) and, in the long term, both supplements added to the bulk noticeably increased E. coli survival after photo-Fenton. SP was successful in increasing bacterial recovery after SODIS and SODIS $+\mathrm{H}_{2} \mathrm{O}_{2}$, as well. Therefore, the excess of $\mathrm{H}_{2} \mathrm{O}_{2}$ that remained in the samples was effectively removed by any of these compounds. Although incubation in anaerobic conditions might have improved the recovery, $48 \mathrm{~h}$ would have been necessary to obtain colonies big enough to be count [22] while $24 \mathrm{~h}$ were sufficient in the aerobic conditions performed in this research.

Kapuscinski et al. [20] consider that the use of catalase might be more recommendable because it is more specific than SP, which could interact with media components. On the other hand, Giandomenico et al. [59], propose that sodium pyruvate generates no toxic products (only acetate and carbon dioxide), whereas with catalase high local oxygen concentrations and peroxidation of other substrates can occur. However, similar bacterial recovery efficiencies after exposure to solar disinfection have been reported either with catalase or with sodium pyruvate [20-22]. A practical issue pointed out by Kehoe et al. [21] is that SP is more stable than catalase at room temperature and, therefore, its action can be more predictable.

\section{Conclusions}

Water treatments based on solar light could efficiently inactivate the bacteria Escherichia coli and prevented its posterior reactivation under the studied conditions (Milli-Q $\mathrm{H}_{2} \mathrm{O}, 900 \mathrm{~W} / \mathrm{m}^{2}$ ). The addition of $10 \mathrm{mg} / \mathrm{L} \mathrm{H}_{2} \mathrm{O}_{2}$ produced faster disinfection and when combined with iron $\left(0.6 \mathrm{mg} / \mathrm{L} \mathrm{Fe}^{2+}\right)$ the effect of internal and external photoFenton was augmented, inducing higher ROS production and consequent increase in bacterial inactivation. 
During the photo-treatments the bacteria experienced different levels of damage, which accumulated as time passed. If the injuries extensively affected DNA and/or vital functions, the cells might have lost their cultivability. When the treated E. coli were plated on the different agars, PCA showed higher counts in all the cases, while the other media (T-7, VRBA, MAC), all of them containing selective substances, inhibited recovery in the short and in the long-term. The results suggest that there is a loss of membrane integrity caused by the photo-treatments and thus, the selective agents might easily be absorbed by the cells, leading to high intracellular concentrations and eventually inactivating the bacteria. However, when spread onto PCA, the presence of nutrients and absence of inhibitors could support the growth of intensively wounded $E$. coli. In addition, the presence of glucose in PCA might benefit the recovery of bacteria whose PEP-PTS system is damaged. So, in general, as selectivity of the media increased bacterial recovery diminished. Moreover, cultivability in selective media was lost before cells were actually inactivated. Therefore, selective media underestimate the real concentration of the targeted bacteria submitted to solar treatments.

Further enhancement of cells recovery was tested by addition of catalase or sodium pyruvate in PCA. Both supplements clearly increased the long-term recovery when added to the bulk, especially after the treatments where extracellular $\mathrm{H}_{2} \mathrm{O}_{2}$ was present (i.e. photo-Fenton and SODIS $+\mathrm{H}_{2} \mathrm{O}_{2}$ ). In addition, the enhanced immediate and longterm E. coli recovery in the presence of SP proves the production and accumulation of intracellular $\mathrm{H}_{2} \mathrm{O}_{2}$ during SODIS, able to reduce post-irradiation survival.

Considering the results obtained in this study, it would be advisable to use PCA containing $100 \mathrm{mM} \mathrm{SP}$ for assessing the disinfection effectiveness of photo-treatments under controlled laboratory conditions in which only a specific bacterium (e.g. E. coli) is present in the sample. However, when facing a real case with natural waters, where a consortium of bacteria and other microorganisms is always present, Tergitol 7 agar 
without TTC would provide good selectivity while minimizing the risks related to the underestimation of Escherichia coli cultivable cells.

\section{Acknowledgements}

The authors thank the Universidad de Zaragoza, Fundación Bancaria Ibercaja and Fundación CAI for the grant awarded to Pilar Valero which enabled a research stay in the EPFL (Switzerland). The authors would also like to acknowledge the Aragón Government for the Ph.D. grant awarded to Pilar Valero, and the European project WATERSPOUTT H2020-Water-5c-2015 (GA 688928) for the financial support.

\section{References}

[1] S. Malato, P. Fernández-lbáñez, M.I. Maldonado, J. Blanco, W. Gernjak, Decontamination and disinfection of water by solar photocatalysis: Recent overview and trends, Catal. Today 147 (2009) 1-59.

[2] K.G. McGuigan, R.M. Conroy, H.-J. Mosler, M.d. Preez, E. Ubomba-Jaswa, P. Fernandez-Ibañez, Solar water disinfection (SODIS): A review from bench-top to rooftop, J. Hazard. Mater. 235-236 (2012) 29-46.

[3] A. Moncayo-Lasso, J. Sanabria, C. Pulgarin, N. Benítez, Simultaneous E. coli inactivation and NOM degradation in river water via photo-Fenton process at natural $\mathrm{pH}$ in solar CPC reactor. A new way for enhancing solar disinfection of natural water, Chemosphere 77 (2009) 296-300.

[4] S. Giannakis, M.I. Polo López, D. Spuhler, J.A. Sánchez Pérez, P. Fernández Ibáñez, C. Pulgarin, Solar disinfection is an augmentable, in situ-generated photoFenton reaction-Part 1: A review of the mechanisms and the fundamental aspects of the process, Appl. Catal., B 199 (2016) 199-223.

[5] S. Giannakis, M.I.P. López, D. Spuhler, J.A.S. Pérez, P.F. Ibáñez, C. Pulgarin, Solar disinfection is an augmentable, in situ-generated photo-Fenton reaction-Part 2: A review of the applications for drinking water and wastewater disinfection, Appl. Catal., B 198 (2016) 431-446.

[6] I. Michael, E. Hapeshi, C. Michael, A.R. Varela, S. Kyriakou, C.M. Manaia, D. FattaKassinos, Solar photo-Fenton process on the abatement of antibiotics at a pilot scale: 
Degradation kinetics, ecotoxicity and phytotoxicity assessment and removal of antibiotic resistant enterococci, Water Res. 46 (2012) 5621-5634.

[7] E. Chatzisymeon, A. Droumpali, D. Mantzavinos, D. Venieri, Disinfection of water and wastewater by UV-A and UV-C irradiation: application of real-time PCR method, Photochem. Photobiol. Sci. 10 (2011) 389-395.

[8] J.M. Willey, L.M. Sherwood, C.J. Woolverton, Microbiología de Prescott, Harley y Klein, 7th ed.2009.

[9] R.M. Atlas, Handbook of Microbiological Media, Fourth Edition, Taylor \& Francis2010.

[10] I. García-Fernández, M.I. Polo-López, I. Oller, P. Fernández-lbáñez, Bacteria and fungi inactivation using $\mathrm{Fe} 3+$ /sunlight, $\mathrm{H}_{2} \mathrm{O} 2$ /sunlight and near neutral photo-Fenton: A comparative study, Appl. Catal., B 121-122 (2012) 20-29.

[11] A. Moncayo-Lasso, L.E. Mora-Arismendi, J.A. Rengifo-Herrera, J. Sanabria, N. Benitez, C. Pulgarin, The detrimental influence of bacteria (E. coli, Shigella and Salmonella) on the degradation of organic compounds (and vice versa) in TiO2 photocatalysis and near-neutral photo-Fenton processes under simulated solar light, Photochem. Photobiol. Sci. 11 (2012) 821-827.

[12] D. Spuhler, J. Andrés Rengifo-Herrera, C. Pulgarin, The effect of $\mathrm{Fe} 2+, \mathrm{Fe}+$, $\mathrm{H} 2 \mathrm{O} 2$ and the photo-Fenton reagent at near neutral $\mathrm{pH}$ on the solar disinfection (SODIS) at low temperatures of water containing Escherichia coli K12, Appl. Catal., B 96 (2010) 126-141.

[13] J. Ndounla, S. Kenfack, J. Wéthé, C. Pulgarin, Relevant impact of irradiance (vs. dose) and evolution of $\mathrm{pH}$ and mineral nitrogen compounds during natural water disinfection by photo-Fenton in a solar CPC reactor, Appl. Catal., B 148-149 (2014) 144-153.

[14] E. Ortega-Gómez, B. Esteban García, M.M. Ballesteros Martín, P. Fernández Ibáñez, J.A. Sánchez Pérez, Inactivation of natural enteric bacteria in real municipal wastewater by solar photo-Fenton at neutral pH, Water Res. 63 (2014) 316-324.

[15] J. Rodríguez-Chueca, M.I. Polo-López, R. Mosteo, M.P. Ormad, P. FernándezIbáñez, Disinfection of real and simulated urban wastewater effluents using a mild solar photo-Fenton, Appl. Catal., B 150-151 (2014) 619-629.

[16] A. Rompré, P. Servais, J. Baudart, M.-R. de-Roubin, P. Laurent, Detection and enumeration of coliforms in drinking water: current methods and emerging approaches, J. Microbiol. Methods 49 (2002) 31-54.

[17] D.L. Scheusner, F.F. Busta, M.L. Speck, Inhibition of Injured Escherichia coli by Several Selective Agents, Applied Microbiology 21 (1971) 46-49.

[18] E. Ubomba-Jaswa, C. Navntoft, M.I. Polo-Lopez, P. Fernandez-lbanez, K.G. McGuigan, Solar disinfection of drinking water (SODIS): an investigation of the effect of UV-A dose on inactivation efficiency, Photochem. Photobiol. Sci. 8 (2009) 587-595. 
[19] S. Giannakis, A.I. Merino Gamo, E. Darakas, A. Escalas-Cañellas, C. Pulgarin, Monitoring the post-irradiation E. coli survival patterns in environmental water matrices: Implications in handling solar disinfected wastewater, Chem. Eng. J. (Lausanne) 253 (2014) 366-376.

[20] R.B. Kapuscinski, R. Mitchell, Solar radiation induces sublethal injury in Escherichia coli in seawater, Appl. Environ. Microbiol. 41 (1981) 670-674.

[21] S.C. Kehoe, M.R. Barer, L.O. Devlin, K.G. McGuigan, Batch process solar disinfection is an efficient means of disinfecting drinking water contaminated with Shigella dysenteriae type I, Letters in Applied Microbiology 38 (2004) 410-414.

[22] R. Khaengraeng, R.H. Reed, Oxygen and photoinactivation of Escherichia coli in UVA and sunlight, J Appl Microbiol 99 (2005) 39-50.

[23] S. Giannakis, A.I. Merino Gamo, E. Darakas, A. Escalas-Cañellas, C. Pulgarin, Impact of different light intermittence regimes on bacteria during simulated solar treatment of secondary effluent: Implications of the inserted dark periods, Solar Energy 98, Part C (2013) 572-581.

[24] M. Berney, H.-U. Weilenmann, T. Egli, Flow-cytometric study of vital cellular functions in Escherichia coli during solar disinfection (SODIS), Microbiology 152 (2006) 1719-1729.

[25] R.P. Sinha, D.P. Hader, UV-induced DNA damage and repair: a review, Photochem. Photobiol. Sci. 1 (2002) 225-236.

[26] J.-H. Yoon, C.-S. Lee, T.R. O'Connor, A. Yasui, G.P. Pfeifer, The DNA damage spectrum produced by simulated sunlight1, J. Mol. Biol. 299 (2000) 681-693.

[27] P.H. Clingen, C.F. Arlett, L. Roza, T. Mori, O. Nikaido, M.H. Green, Induction of cyclobutane pyrimidine dimers, pyrimidine(6-4)pyrimidone photoproducts, and Dewar valence isomers by natural sunlight in normal human mononuclear cells, Cancer Res. 55 (1995) 2245-2248.

[28] J.-L. Ravanat, T. Douki, J. Cadet, Direct and indirect effects of UV radiation on DNA and its components, J. Photochem. Photobiol., B 63 (2001) 88-102.

[29] G.P. Pfeifer, Y.-H. You, A. Besaratinia, Mutations induced by ultraviolet light, Mutation Research/Fundamental and Molecular Mechanisms of Mutagenesis 571 (2005) 19-31.

[30] J.A. Imlay, Pathways of oxidative damage, Annu. Rev. Microbiol. 57 (2003) 395418.

[31] P.E. Hockberger, T.A. Skimina, V.E. Centonze, C. Lavin, S. Chu, S. Dadras, J.K. Reddy, J.G. White, Activation of flavin-containing oxidases underlies light-induced production of $\mathrm{H} 2 \mathrm{O} 2$ in mammalian cells, Proceedings of the National Academy of Sciences 96 (1999) 6255-6260. 
[32] C. Pourzand, R.D. Watkin, J.E. Brown, R.M. Tyrrell, Ultraviolet A radiation induces immediate release of iron in human primary skin fibroblasts: The role of ferritin, Proceedings of the National Academy of Sciences 96 (1999) 6751-6756.

[33] J. Hoerter, A. Pierce, C. Troupe, J. Epperson, A. Eisenstark, Role of Enterobactin and Intracellular Iron in Cell Lethality During Near-UV Irradiation in Escherichia coli, Photochem. Photobiol. 64 (1996) 537-541.

[34] E. Cabiscol, J. Tamarit, J. Ros, Oxidative stress in bacteria and protein damage by reactive oxygen species, Int Microbiol 3 (2000) 3-8.

[35] C. Ruales-Lonfat, J.F. Barona, A. Sienkiewicz, M. Bensimon, J. VélezColmenares, N. Benítez, C. Pulgarín, Iron oxides semiconductors are efficients for solar water disinfection: A comparison with photo-Fenton processes at neutral $\mathrm{pH}$, Appl. Catal., B 166-167 (2015) 497-508.

[36] W. Feng, D. Nansheng, Photochemistry of hydrolytic iron (III) species and photoinduced degradation of organic compounds. A minireview, Chemosphere 41 (2000) 1137-1147.

[37] J.M.C. Robertson, P.K. J. Robertson, L.A. Lawton, A comparison of the effectiveness of $\mathrm{TiO} 2$ photocatalysis and UVA photolysis for the destruction of three pathogenic micro-organisms, J. Photochem. Photobiol., A 175 (2005) 51-56.

[38] J.D. Hoerter, A.A. Arnold, D.A. Kuczynska, A. Shibuya, C.S. Ward, M.G. Sauer, A. Gizachew, T.M. Hotchkiss, T.J. Fleming, S. Johnson, Effects of sublethal UVA irradiation on activity levels of oxidative defense enzymes and protein oxidation in Escherichia coli, J. Photochem. Photobiol., B 81 (2005) 171-180.

[39] J.A. Imlay, Cellular defenses against superoxide and hydrogen peroxide, Annu. Rev. Biochem. 77 (2008) 755-776.

[40] L. Fiksdal, I. Tryland, Effect of u.v. light irradiation, starvation and heat on Escherichia coli beta-D-galactosidase activity and other potential viability parameters, $\mathrm{J}$ Appl Microbiol 87 (1999) 62-71.

[41] A. Hörman, M.-L. Hänninen, Evaluation of the lactose Tergitol-7, m-Endo LES, Colilert 18, Readycult Coliforms 100, Water-Check-100, 3M Petrifilm EC and DryCult Coliform test methods for detection of total coliforms and Escherichia coli in water samples, Water Res. 40 (2006) 3249-3256.

[42] A.L. Pollard, A useful selective bactericidal property of tergitol-7, Science 103 (1946) 758-759.

[43] D.Y. Fung, R.D. Miller, Effect of dyes on bacterial growth, Applied microbiology 25 (1973) 793-799.

[44] D.G. Thanassi, L.W. Cheng, H. Nikaido, Active efflux of bile salts by Escherichia coli, J. Bacteriol. 179 (1997) 2512-2518.

[45] T. Fujisawa, M. Mori, Influence of bile salts on beta-glucuronidase activity of intestinal bacteria, Lett Appl Microbiol 22 (1996) 271-274. 
[46] C. Bernstein, H. Bernstein, C.M. Payne, S.E. Beard, J. Schneider, Bile salt activation of stress response promoters in Escherichia coli, Curr. Microbiol. 39 (1999) 68-72.

[47] C.E. Hoffmann, O. Rahn, The bactericidal and bacteriostatic action of crystal violet, J. Bacteriol. 47 (1944) 177-186.

[48] E. Adams, The antibacterial action of crystal violet*, J. Pharm. Pharmacol. 19 (1967) 821-826.

[49] F. Kastury, A. Juhasz, S. Beckmann, M. Manefield, Ecotoxicity of neutral red (dye) and its environmental applications, Ecotoxicol. Environ. Saf. 122 (2015) 186-192.

[50] J.G. Lawrence, J.R. Roth, Evolution of Coenzyme B(12) Synthesis among Enteric Bacteria: Evidence for Loss and Reacquisition of a Multigene Complex, Genetics 142 (1996) 11-24.

[51] G.A. McFeters, S.C. Cameron, M.W. LeChevallier, Influence of diluents, media, and membrane filters on detection fo injured waterborne coliform bacteria, Appl. Environ. Microbiol. 43 (1982) 97-103.

[52] E. Painbeni, M. Caroff, J. Rouviere-Yaniv, Alterations of the outer membrane composition in Escherichia coli lacking the histone-like protein HU, Proc. Natl. Acad. Sci. U. S. A. 94 (1997) 6712-6717.

[53] S.M. Gubash, C.M. Anand, M. Stokman, Inhibition of Escherichia coli serotype O157:H7 by bromthymol blue, J. Clin. Microbiol. 26 (1988) 2248-2249.

[54] P.R. Rich, L.A. Mischis, S. Purton, J.T. Wiskich, The sites of interaction of triphenyltetrazolium chloride with mitochondrial respiratory chains, FEMS Microbiol. Lett. 202 (2001) 181-187.

[55] P. Gustafsson, K. Nordström, S. Normark, Outer Penetration Barrier of Escherichia coli K-12: Kinetics of the Uptake of Gentian Violet by Wild Type and Envelope Mutants, J. Bacteriol. 116 (1973) 893-900.

[56] C.-C. Chou, S.-J. Cheng, Recovery of low-temperature stressed E. coli O157:H7 and its susceptibility to crystal violet, bile salt, sodium chloride and ethanol, International Journal of Food Microbiology 61 (2000) 127-136.

[57] K.A. Nath, E.O. Ngo, R.P. Hebbel, A.J. Croatt, B. Zhou, L.M. Nutter, alphaKetoacids scavenge $\mathrm{H} 2 \mathrm{O} 2$ in vitro and in vivo and reduce menadione-induced DNA injury and cytotoxicity, Am. J. Physiol. 268 (1995) C227-236.

[58] S.K. Mani, R. Kanjur, I.S. Bright Singh, R.H. Reed, Comparative effectiveness of solar disinfection using small-scale batch reactors with reflective, absorptive and transmissive rear surfaces, Water Res. 40 (2006) 721-727.

[59] A.R. Giandomenico, G.E. Cerniglia, J.E. Biaglow, C.W. Stevens, C.J. Koch, The importance of sodium pyruvate in assessing damage produced by hydrogen peroxide, Free Radic Biol Med 23 (1997) 426-434. 
Table 1. Culture media composition

\begin{tabular}{rccccc}
\hline & PCA & LBA & Tergitol-7 & VRBA & MAC \\
\hline Tryptone $(\mathrm{g} / \mathrm{L})$ & - & 10 & - & - & - \\
Peptone from caseine (g/L) & 5 & - & - & - & - \\
Peptone (g/L) & - & - & 5 & - & 17 \\
Peptone from gelatin (g/L) & - & - & - & 7 & - \\
Proteose peptone (g/L) & - & - & - & - & 3 \\
Yeast extract (g/L) & 2.5 & 5 & 3 & 3 & - \\
NaCl (g/L) & - & 10 & - & 5 & 5 \\
Agar (g/L) & 14 & 15 & 15 & 12 & 13.5 \\
D(+)-Glucose (g/L) & - & - & - & - & - \\
Lactose (g/L) & - & - & 10 & 10 & 10 \\
Tergitol- 7 (g/L) & - & - & 0.1 & - & - \\
Bile salts (g/L) & - & - & 0.025 & - & - \\
Crystal violet (g/L) & - & - & - & 1.5 & 1.5 \\
Neutral red (g/L) & - & - & - & 0.002 & 0.001 \\
TTC (g/L) & - & - & - & 0.03 & 0.03 \\
\hline
\end{tabular}

${ }^{*}$ Tergitol-7 Agar was tested with and without TTC supplement 
Table 2. Summary of estimated inactivation rate constants $\left(k_{t}\left[\mathrm{~min}^{-1}\right]\right)$ in the different media assuming first order kinetics during post-SODIS survival in the dark.

\begin{tabular}{r|cccc}
\hline Treatment time (min) & PCA & T-7 & VRBA & MAC \\
\hline 0 & 0.003 & 0.002 & 0.011 & 0.005 \\
30 & 0.009 & 0.020 & 0.028 & 0.007 \\
60 & 0.027 & 0.044 & 0.048 & - \\
90 & 0.028 & 0.078 & 0.076 & - \\
120 & 0.033 & 0.105 & - & - \\
180 & 0.033 & - & - & - \\
\hline
\end{tabular}




\section{Figure 1 caption}

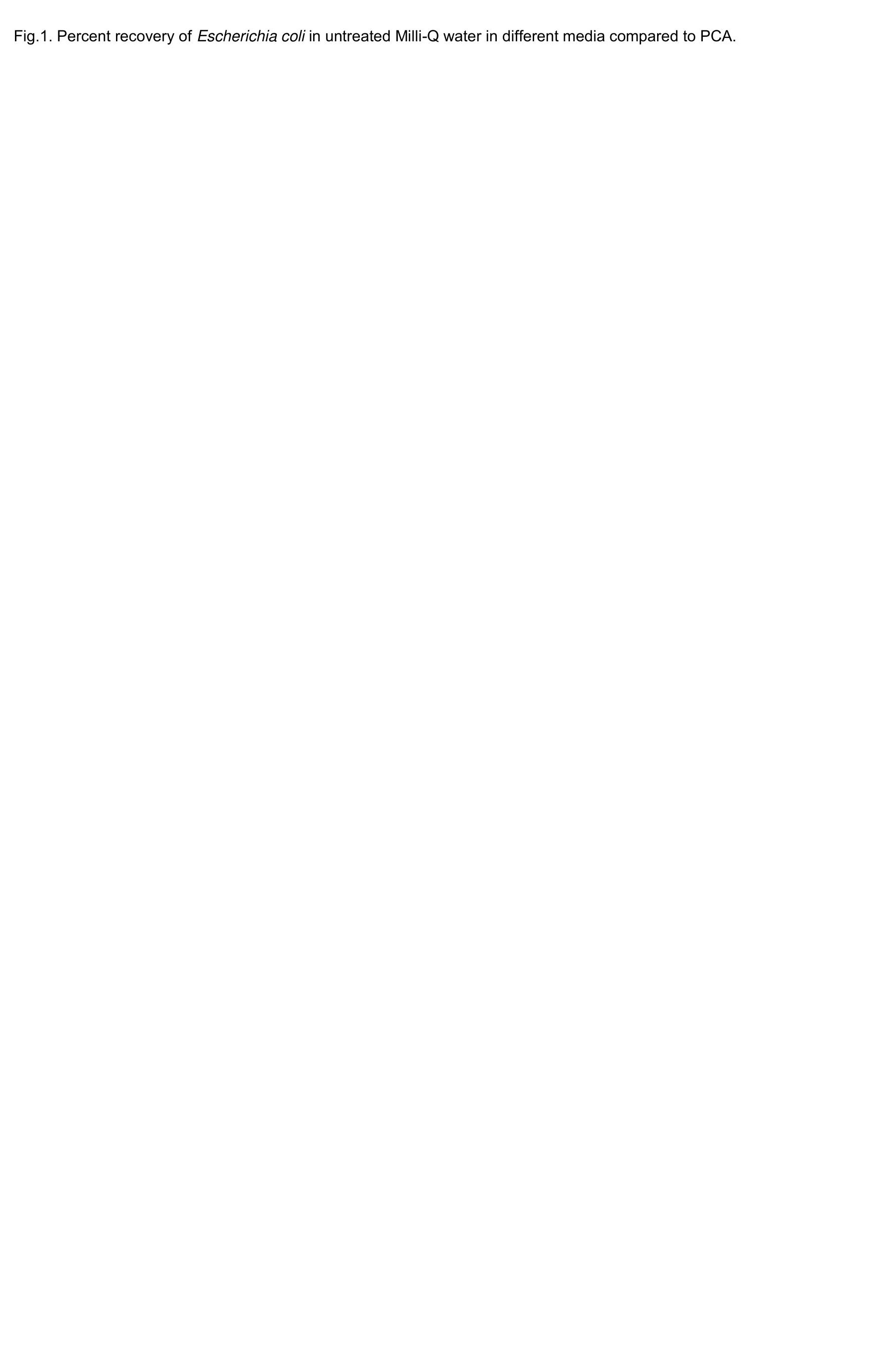

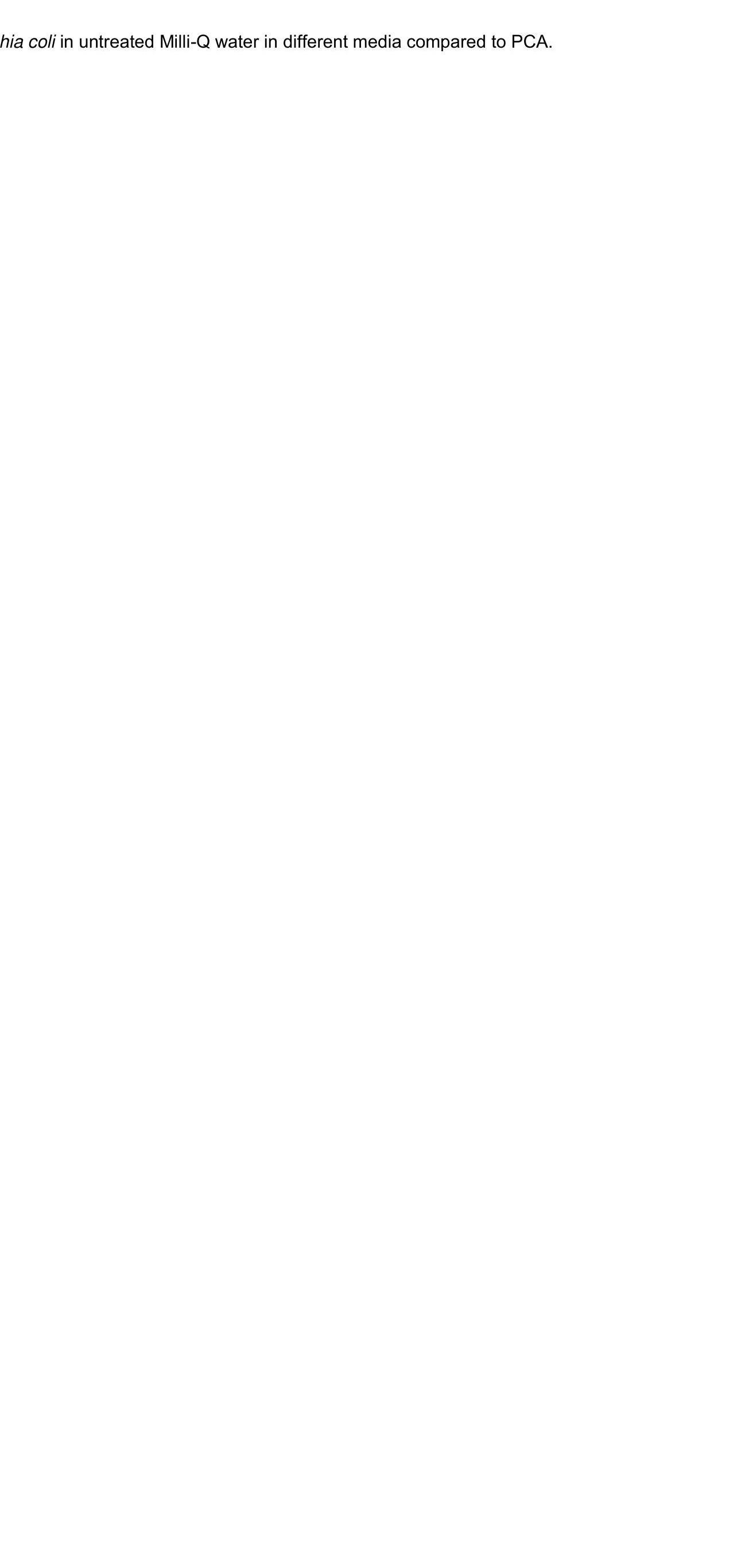
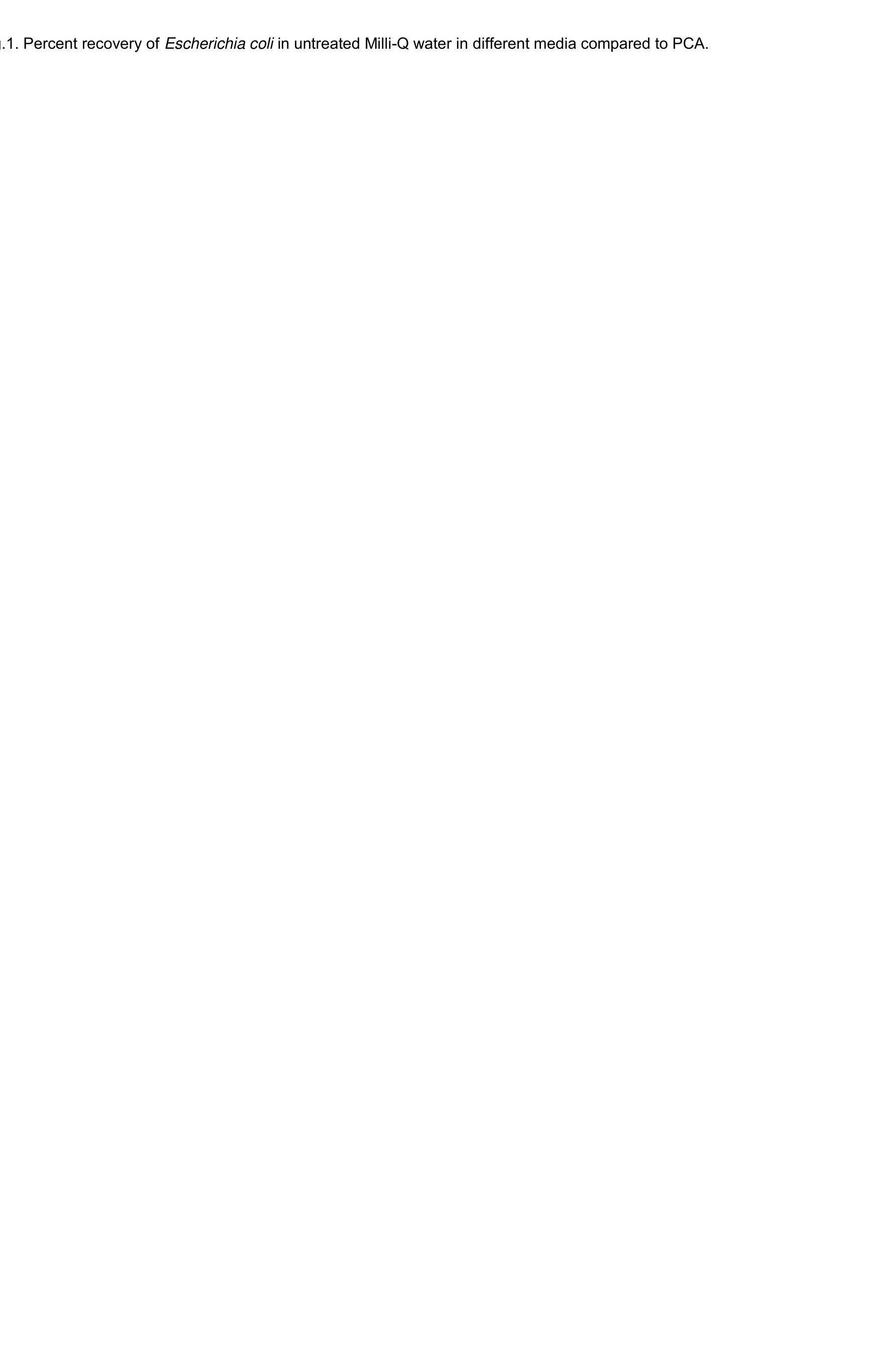
Figure 2
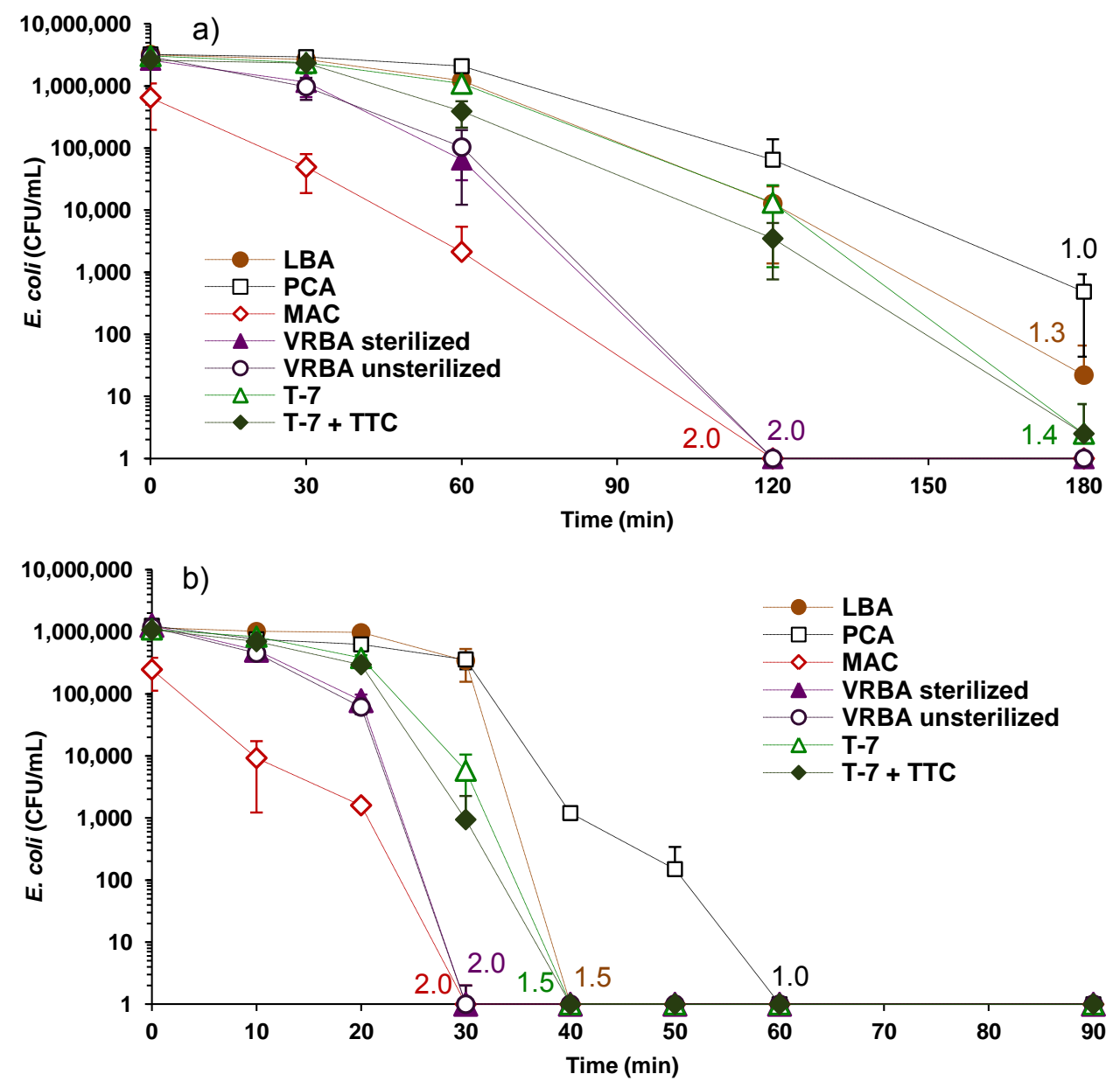
Fig. 2. E. coli immediate recovery in different media after a) Solar Disinfection and b) photo-Fenton. Values included in the figures correspond to the growth restriction ratio of each medium. 
Figure 3
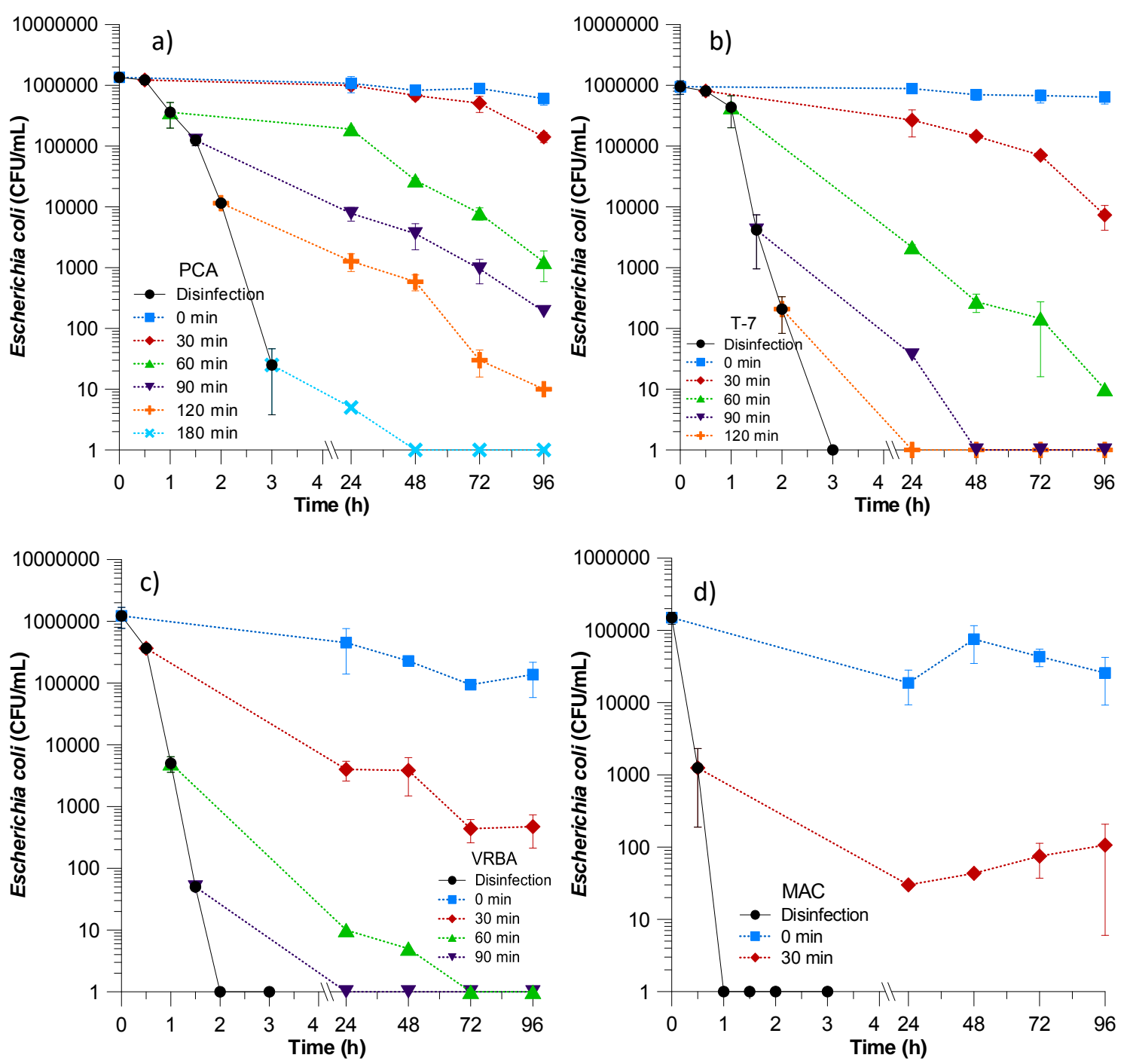
Figure 3

Fig. 3. Post-SODIS survival of E.coli stored in the dark at $29.5 \pm 0.5^{\circ} \mathrm{C}$ and plated on different media: a) PCA; b) Tergitol-7 Agar; c) VRBA; d) MacConkey Agar. 

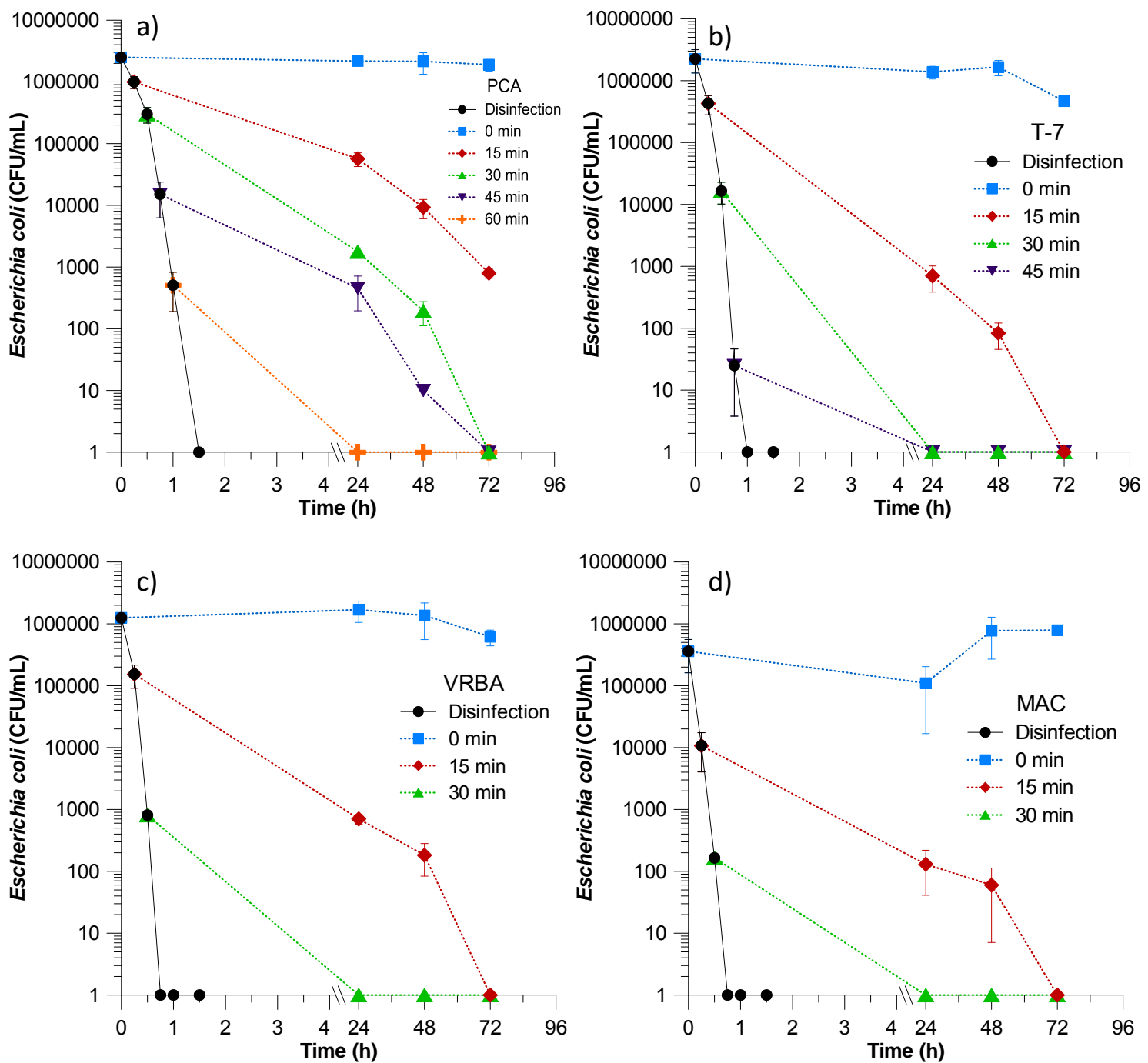
Figure 4_caption

Fig. 4. Post-photo-Fenton survival of E.coli stored with catalase addition in the dark at $29.5 \pm 0.5^{\circ} \mathrm{C}$ and

\begin{abstract}
plated on different media: a) PCA; b) Tergitol-7 Agar; c) VRBA; d) MacConkey Agar.
\end{abstract}


Figure 5 caption

Fig. 5. E. coli immediate recovery in PCA supplemented with different concentrations of sodium pyruvate after a) SODIS, b) SODIS $+\mathrm{H}_{2} \mathrm{O}_{2}$ and c) photo-Fenton. 

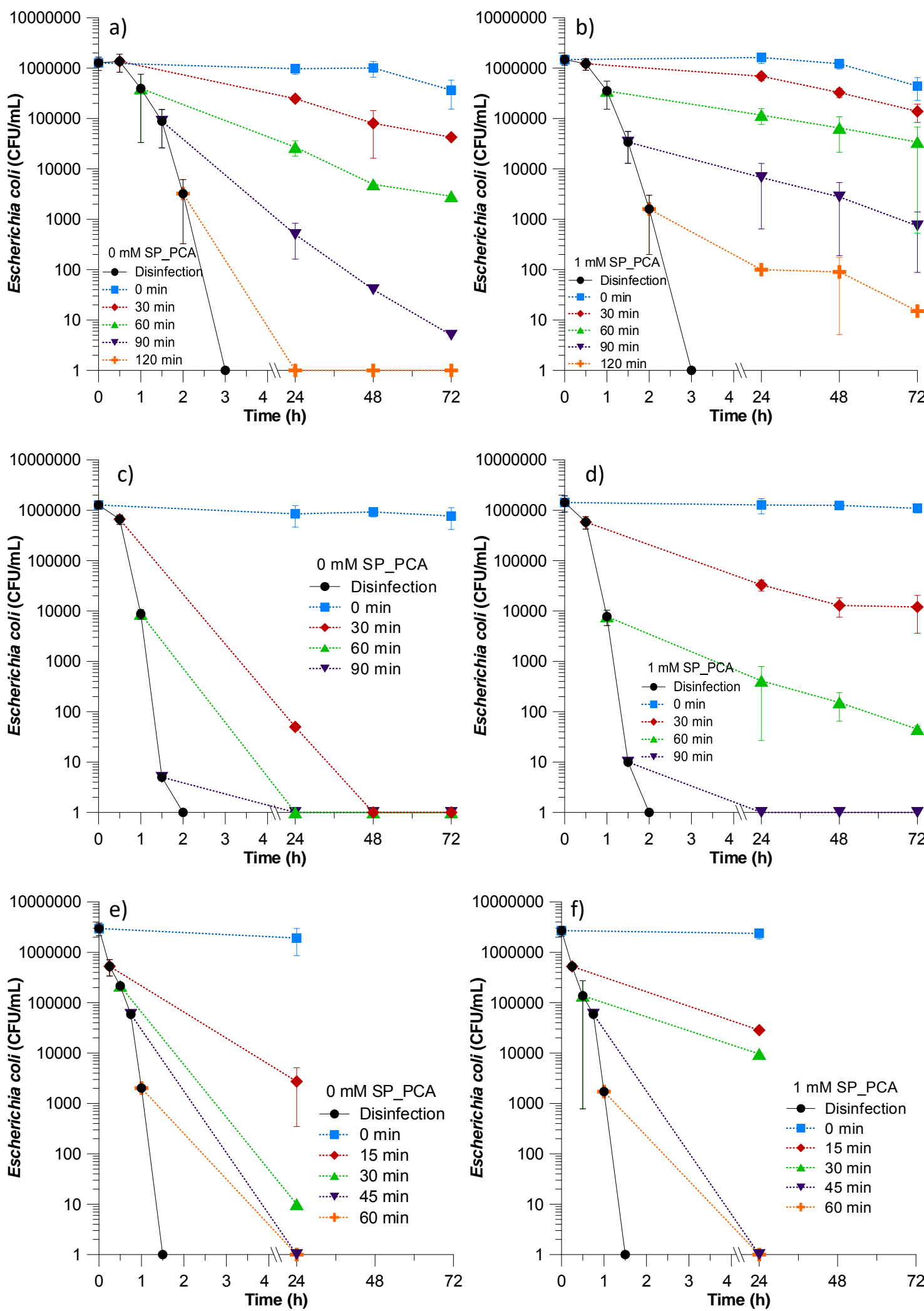
Figure 6_caption

Fig. 6. Survival of E.coli stored in the dark at $29.5 \pm 0.5^{\circ} \mathrm{C}$ and plated on PCA after: a) SODIS (0 mM SP), b) SODIS and addition of sodium pyruvate (1 mM SP), c) SODIS $+\mathrm{H}_{2} \mathrm{O}_{2}(0 \mathrm{mM} \mathrm{SP})$, d) $\mathrm{SODIS}+\mathrm{H}_{2} \mathrm{O}_{2}$ and addition of sodium pyruvate (1 $\mathrm{mM} \mathrm{SP}), e)$ photo-Fenton $(0 \mathrm{mM} \mathrm{SP}), \mathrm{f})$ photo-Fenton and addition of sodium pyruvate (1 $\mathrm{mM} \mathrm{SP})$. 